\title{
Psychosocial factors, work stress and its relationship with labor alienation in organizations
}

\section{Los factores psicosociales, el estrés laboral y su relación con la alienación laboral en las organizaciones}

RUÍZ-VALDÉS, Susana†*, RUÍZ-TAPIA, Juan Alberto, ALCÁNTARA-CRUZ, Felix Héctor and HERNÁNDEZ-MARTÍNEZ, Maria Luisa

\section{Universidad Autónoma del Estado de México}

ID $1^{\text {st }}$ Author: Susana, Ruíz-Valdés / ORC ID: 0000-0001-6318-3009, arXiv Author ID: Susanaruíz, CVU CONACYT ID: 402668

ID $1^{\text {st }}$ Co-author: Juan Alberto, Ruíz-Tapia / ORC ID: 0000-0003-1436-5214, arXiv Author ID: Juanalbertoruíz, CVU CONACYT ID: 69481

ID $2^{\text {nd }}$ Co-author: Felix Héctor, Alcántara-Cruz

ID $3^{\text {rd }}$ Co-author: Maria Luisa, Hernández-Martínez.

DOI: $10.35429 / J H R T .2021 .19 .7 .6 .12$

Received: March 30, 2021; Accepted: July 21, 2021

\section{Abstract}

Changes in work rhythms in these times have led to the emergence of different behaviors in the collaborators of organizations, severely affecting their social, physical, mental and emotional health. The purpose of this research has to characterize work alienation in organizations as highly interrelated psychosocial risk factors and work stress as a consequence of the dynamism of the environment in which current organizations find themselves. Its main objective is to determine the relationship between work alienation, Psycosocial Factors at Work and Work Stress in employees of a business integration company. The methodology is the construction of the research is descriptive in the research process, observing the behavior of these variables in their natural context; by selecting and reviewing different documentary sources. The results obtained are summarized in observations made on the theoretical and practical interrelation that is deduced between these constructs. Main aspects of work alienation are presented, psychosocial factors and work stress issues are addressed, what it is and how they originate, and how to reduce them. Finally, a proposal is presented as a means for counteracting these effects among the collaborators of an organization.

Psychosocial factors, Stress, Job alienation

\section{Resumen}

Los cambios en los ritmos de trabajo en estos tiempos han hecho que surjan diferentes comportamientos en los colaboradores de las organizaciones afectando severamente su salud social, física, mental y emocional.Esta investigación tiene como finalidad caracterizar la alienación laboral en las organizaciones como factores de riesgo psicosocial y el estrés laboral fuertemente interrelacionados como consecuencia del dinamismo del entorno en el que se encuentran las organizaciones actuales. Su objetivo principal es determinar la relación entre la alienación laboral, los Factores Psicosociales en el Trabajo y Estrés Laboral en los colaboradores de una empresa integradora de negocio. La metodología es la construcción de la investigación es de tipo descriptivo en el proceso de investigación, observándose el comportamiento de estas variables en su contexto natural; mediante la selección y revisión de distintas fuentes documentales. Los resultados obtenidos se resumen en observaciones hechas sobre la interrelación teórica y práctica que se deduce entre estos constructos. Se presentan aspectos principales de la alienación laboral, se abordan temas de factores psicosociales y estrés laboral, qué es y cómo se originan, y como poder disminuirlos. Finalmente, se presenta una propuesta como medio para contrarrestar estos efectos entre los colaboradores de una organización.

Factores psicosociales, estrés, Alienación laboral

Citation: RUÍZ-VALDÉS, Susana, RUÍZ-TAPIA, Juan Alberto, ALCÁNTARA-CRUZ, Felix Héctor and HERNÁNDEZMARTÍNEZ, Maria Luisa. Psychosocial factors, work stress and its relationship with labor alienation in organizationsJournal of Human Resources Training. 2021, 7-19: 6-12

*Correspondence to Author (email: srv_cm@ hotmail.com)

$\dagger$ Researcher contributing first Author 


\section{Introduction}

Currently, organizations are in constant movement marked by the dynamism of the environment in which we find ourselves, so research and under the interest of literature on organizational psychology and human resources management, the causes of work alienation and the effects are sought. that can cause in employees such as psychosocial risks and job stress. The changes in the work rhythms in which we develop in these times of pandemic have caused deviant behaviors to emerge in the collaborators of the organizations, severely affecting their social, physical, mental and emotional health.

\section{Theoretical framework}

The way to analyze the alienated behavior of workers and the transformations underway with the current socio-economic crisis force us to reread the psychosocial factors that impact an organization; in order to understand them and adopt preventive and corrective actions that prevent the current degradation of working conditions (Jara, 1999). The postulates about job alienation imply the onset of psychosocial risks and job stress with serious consequences for workers; therefore, its study must be taken into account by the companies towards their workers.

Alonso (1973) suggests that alienation implies a disconnection or uprooting of the individual from things, people, and ideas of the world around him. The work environment is one of the contexts in which individuals can experience alienation going unnoticed or unnoticed; since people themselves do not realize this condition; For example, a worker who feels jaded, disenchanted, bored, annoyed, tired in his work or frustrated by the functions or activities of his position, does not realize his job alienation and the psychosocial risk factors that arise in them. Labor alienation (AL, hereinafter) has its origin in the writings of the German philosopher Karl Marx (1844), understood as the result of a contradiction between the work of an employee and his own human nature.

As a result it represents the loss of its own identity; In other words, the worker does not find meaning in his work tasks and may present symptoms of disorientation, incapacity or impotence, as well as insignificance and isolation (Gurmendez, 1989).
Thus, given the lack of identity of the individual with the organization, a series of effects or behaviors are generated in the employee that affect their performance (Pando, Román \& Acosta, 2008). If we want to analyze the work environment and psychosocial risk factors, we must take into account the different dimensions from which these behaviors can be understood:

- The individual dimension, aimed at knowing the profile of the company's workers to identify which people, due to their personality traits, may present greater psychosocial risks.

- The organizational dimension, designed to review aspects related to the operation of a company, such as the distribution of work, working hours, production method, type of work that is carried out that can generate work stress.

- The macrosocial dimension, which would be dedicated to understanding the functioning of individuals within an organization and their behavior outside it, attending to all those spheres that directly or indirectly affect interpersonal relationships.

Starting from the expansion of the work alienation construct exposed in research by (Alonso, 1973), three features are also presented within LA to consider: powerlessness, meaninglessness, normlessness, isolation and self-strangement.

- Powerlessness refers to the feeling of lack of control or powerlessness over the performance of their daily work that an employee experiences.

- Meaninglessness as the feeling on the part of the employee that his work is not relevant in the productive process of the organization.

- $\quad$ Normlessnes or the absence of norms in which workers feel that the norms are scarce, confusing or that they have lost their value.

- Isolation as the feeling of isolation or lack of identification of the worker with his organization 
- $\quad$ Self-strangement that would be present when the worker does not feel fulfilled with the work he performs.

According to this approach, LA are conditions that can give off psychosocial risk factors in the health of the worker.

For the ILO (1986) the psychosocial factors at work are: “... Interactions between work, its environment, job satisfaction and the conditions of its organization, on the one hand, and the worker's capabilities on the other. , their needs, their culture and their personal situation outside of work, all of which, through perceptions and experiences, can influence health and job performance and satisfaction. " (p. 12).

Likewise, psychosocial factors at work represent a set of perceptions and experiences of the worker and include: individual or personal factors of the worker, working conditions and environment, and external factors that include economic and social conditions outside the workplace and that have an impact on it (ILO, 1986). Figure 1.

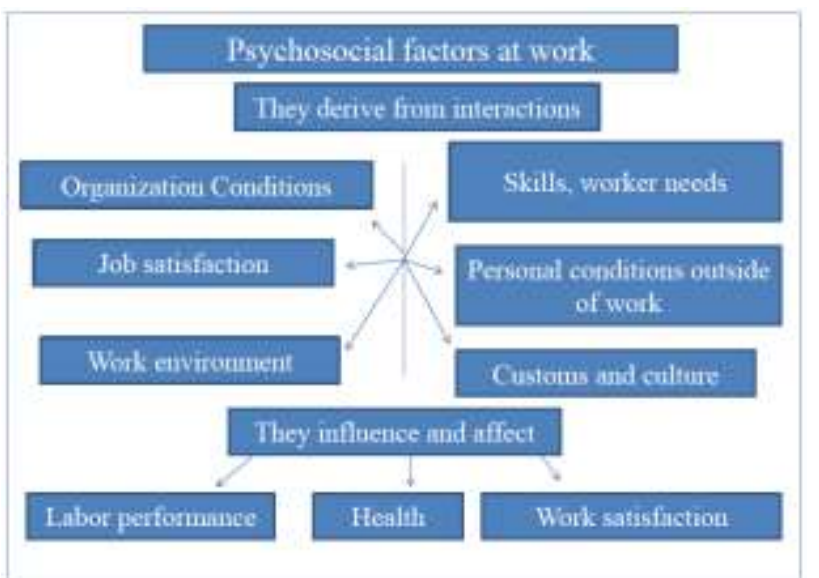

Figure 1 Psychosocial factors at work Source: (ILO, 1986)

These factors provoke responses of maladjustment, tension and stress affecting the health and well-being of the worker (Benavides, Gimeno, Benach, Martínez, Jarque, Berra, 2002). Therefore, it is necessary to understand that LA is a phenomenon in which human beings manifest different situations, behaviors or feelings of people;
However, the curious fact is how organizations control and cancel their free will, to make the person dependent on their daily work activities, making them alienated, therefore alienation is a problem that can affect the different social contexts of the human being as It is at the family level, in interpersonal relationships and in the workplace, that is, psychosocial risk factors, so studies on this phenomenon must be deepened to know the effects it generates on human beings.

It should be noted that LA worsens when work has less meaning for the worker (Isolation), when the reward system is more linked to factors external to the productivity of the individual (Normlessnes) and when the organization offers the worker less means to perform their own goals (Meaninglessness). Specifically, LA is translated by a feeling of powerlessness, lack of power and strangeness with respect to work and others (Po-werlessness), a loss of confidence in the "I" (Self-strangement), a dissatisfaction with regard to work and an inability to integrate the values disseminated by the organization "(Duro, 2005).

Based on the different sources consulted, the problems that can be addressed using the methodological approaches to LA are the psychosocial risk factors (work contexts that usually damage the health of the worker in a significant way), whose effects on each worker can be differential, among which are: work stress, work violence, workplace harassment, sexual harassment, contractual insecurity, burnout, work-family conflict, infidelity, among others. All these contexts must have an evident possibility of damaging the physical, social or mental health of the worker so that they are proposed as occupational psychosocial risk factors (Juárez and Camacho, 2011).

As already mentioned, psychosocial risk factors are not only con-formed by variables of the work environment, but also by personal variables of the collaborator such as attitude, perceptions, experiences, motivation, training, capacities, resources personal and professional; This means that the environment and the personality of the collaborator influence the perception of reality in response to different work situations. 
Acevedo, Sánchez, Farías and Fernández (2013) mention that psychosocial risks concentrate on average one third of work-related accidents and illnesses; $17 \%$ sick leave and $30 \%$ work stress. This reflects that the reciprocal action between the collaborator and their environment can affect their health when they are subjected to stress or that they exceed their tolerance level, and can cause diseases or aggravate previous ailments (Jiménez and León 2010).

To develop adequate preventive activity in the field of psychosocial risk factors, it is important to differentiate the meaning of some concepts. Working conditions is the fusion of variables that determine the performance of a task in an environment; that is, those circumstances that determine the state of our work environment, ranging from the tasks we perform to the type of relationship we maintain inside and outside the company (ILO, 1986).

When we talk about psychosocial factors, we refer to the work conditions of a psychological and / or social nature, which characterize our work environment (interpersonal relationships, workload, organizational climate, leadership, communication, identification, autonomy , psychological contract) (ILO, 1986). These conditions become risk factors that can cause damage or trigger some negative alteration in the worker's level of health.

Thus, a psychosocial factor is any aspect related to the conception and management of work, with its labor and social context that has the potential to cause a negative effect on the health of the organization's workers (ILO, 1986).

It should be taken into account that work stress is one of the main psychosocial risk factors present in organizations, induced by the increase in workload, greater demands, new work rates at home where mental work has exceeded physical work and that negatively affect their health (Noriega et al, 2000). Thus evidencing the leading role that LA has and its consequences.

From all the aforementioned, it allows us to support the following research question: How do psychosocial factors at work impact on job alienation and job stress in employees?
The problem of this research topic responds to the need to know the effects of LA, psychosocial factors and work stress on the health of employees of a Business Integrating company, its turn is focused on carrying out consulting and supervision services located in Toluca, State of Mexico. This business was chosen because it is considered to suffer from $\mathrm{AL}$ in its collaborators.

Knowing the dynamics of these variables will allow to identify points of improvement, being necessary to involve all collaborators in the feedback process, in order to achieve a change in the prevention of unfavorable consequencs in physical and mental health.

The main objective of this research is: to determine the relationship between LA, Psychosocial Factors at Work and Work Stress in collaborators of an integrating business company.

The information presented is descriptive in the research process, observing the behavior of these variables in their natural context; the design of the research is non-experimental, transversal because it investigates the present state of the functioning of a behavior.

The study population is the headquarters of the organization, which has a total of 83 collaborators after discarding all absent personnel who were not present during the evaluation process for various reasons.

Data collection was carried out in a Census form, since all the organization's collaborators participate, therefore, there was no sample or sampling strategy to determine the eligible population.

As a research assumption, it is necessary to: if the psychosocial factors can be identified, it will reduce the effects of work alienation in the collaborators of this business integrating company.

\section{Measurement tools}

\section{Draft NOM-035-STPS2018 Risk Factors}

Questionnaire 1: Reference Guide I. Questionnaire to identify workers who were subjected to severe traumatic events. 
- Questionnaire: Reference Guide II Identification of psychosocial risk.

- Questionnaire: Reference Guide III. Identification of psychosocial risk factors and evaluation of the organizational environment in the work centers.

The evaluation of the questionnaires was coordinated with the Human Resources area of the company in order to identify harmful aspects that are present and that could affect the quality of life of the collaborators.

A diagnosis was made using the following points (Table 1):

- Identification: It consists of the identification and description of the presence of psychosocial risk factors or psychosocial risks (and their effects) according to a theoretical and methodological foundation.

- Evaluation: Measure the characteristics or variables to assess the degree of risk or stress present in workers and the consequences or effects on health.

- $\quad$ Measurement: Assignment of numbers to the characteristics or variables of the units of analysis according to certain rules to make the presence of these variables evident.

\section{Analysis of data}

After collecting and coding the data for each questionnaire, a descriptive analysis of the variables was carried out. These results were tabulated and analyzed (Table 2).
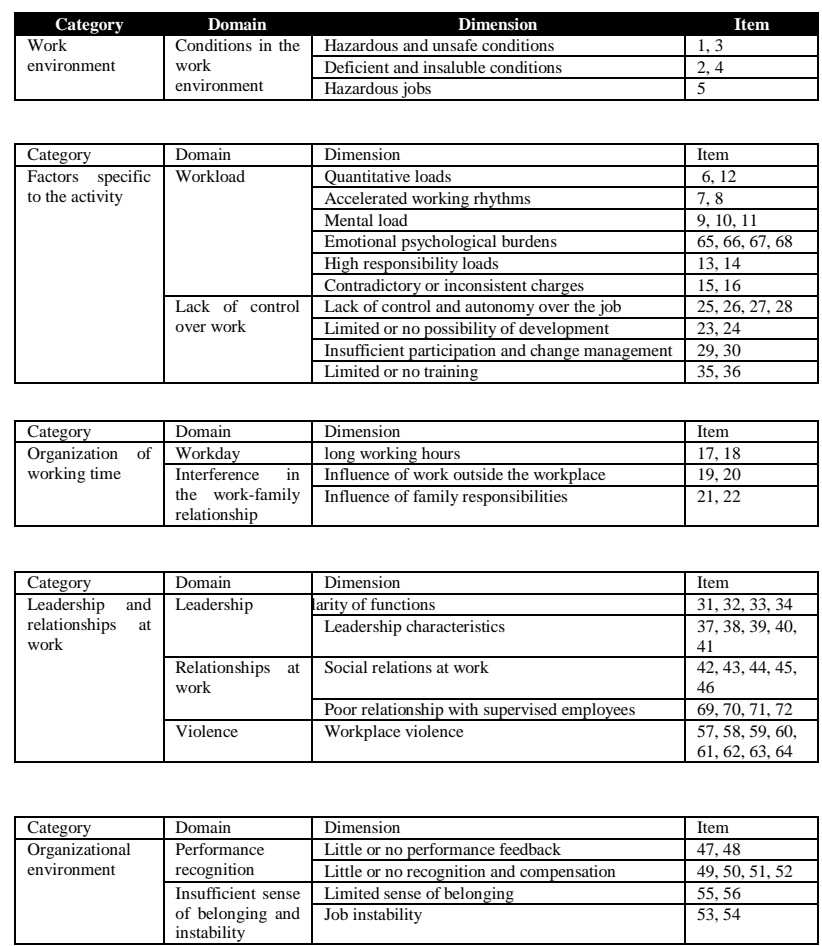

Table 1 Identification: Conditions in the work environment

Source: Self Made

\begin{tabular}{|l|l|}
\hline \multicolumn{1}{|c}{ Nom 035 } & Group \\
\hline Final grade of the questionnaire Cfinal & High \\
\hline Category rating & \\
\hline Work environment & Under \\
\hline Factors specific to the activity & High \\
\hline Organization of working time & Very high \\
\hline Leadership and relationships at work & Under \\
\hline Organizational environment & Under \\
\hline Domain qualification & \\
\hline Conditions in the work environment & Under \\
\hline Workload & Muy alto \\
\hline Lack of control over work & Under \\
\hline Workday & High \\
\hline Interference in the work-family relationship & High \\
\hline Leadership & Null \\
\hline Relationships at work & Null \\
\hline Violence & Medium \\
\hline Performance recognition & Under \\
\hline Insufficient sense of belonging and instability. & Under \\
\hline
\end{tabular}

Table 2 Research results

Source: Self Made 


\begin{tabular}{|c|c|c|}
\hline Category & Domain & Organizational actions \\
\hline $\begin{array}{l}\text { Work } \\
\text { environment }\end{array}$ & $\begin{array}{l}\text { Conditions in } \\
\text { the work } \\
\text { environment }\end{array}$ & $\begin{array}{l}\text { Revision of the health and safety } \\
\text { protocol. Ergonomics and } \\
\text { environmental design (improve } \\
\text { equipment used at work and } \\
\text { physical working conditions). }\end{array}$ \\
\hline \multirow[t]{4}{*}{$\begin{array}{l}\text { Factors } \\
\text { specific to the } \\
\text { activity }\end{array}$} & \multirow[t]{3}{*}{ Workloads } & $\begin{array}{l}\text { Review and supervision that the } \\
\text { distribution and workloads are } \\
\text { carried out equitably and } \\
\text { considering the number of workers, } \\
\text { activities to be developed, scope of } \\
\text { the activity and their training; } \\
\text { processes and procedures that } \\
\text { clearly define tasks and } \\
\text { responsibilities. }\end{array}$ \\
\hline & & $\begin{array}{l}\text { Activities to plan the work, } \\
\text { considering the production process } \\
\text { in order to have the necessary } \\
\text { breaks or rest periods, rotation of } \\
\text { tasks and other necessary measures } \\
\text { to avoid accelerated work rhythms. }\end{array}$ \\
\hline & & $\begin{array}{l}\text { Ensuring that employees have or } \\
\text { can acquire the knowledge and } \\
\text { skills necessary to perform their } \\
\text { duties effectively }\end{array}$ \\
\hline & $\begin{array}{l}\text { Lack of control } \\
\text { over work }\end{array}$ & $\begin{array}{l}\text { Increase in the quality and quantity } \\
\text { of support received by the } \\
\text { employee for the development of } \\
\text { his/her activities. }\end{array}$ \\
\hline \multirow[t]{2}{*}{$\begin{array}{l}\text { Organization } \\
\text { of time at work }\end{array}$} & Workday & $\begin{array}{l}\text { Actions to involve employees in } \\
\text { defining work schedules, when } \\
\text { work conditions allow it. }\end{array}$ \\
\hline & $\begin{array}{l}\text { Interference in } \\
\text { the work- } \\
\text { family } \\
\text { relationship }\end{array}$ & $\begin{array}{l}\text { Guidelines to establish measures } \\
\text { and limits to avoid working hours } \\
\text { in excess of those established in the } \\
\text { LFT. }\end{array}$ \\
\hline \multirow{8}{*}{$\begin{array}{l}\text { Leadership } \\
\text { and } \\
\text { relationships } \\
\text { at work }\end{array}$} & \multirow[t]{2}{*}{ Leadership } & $\begin{array}{l}\text { Work time distribution and priority } \\
\text { setting }\end{array}$ \\
\hline & & $\begin{array}{l}\text { Actions for conflict management at } \\
\text { work }\end{array}$ \\
\hline & \multirow[t]{3}{*}{$\begin{array}{l}\text { Relationships at } \\
\text { work }\end{array}$} & $\begin{array}{l}\text { Mechanisms to promote } \\
\text { communication } \\
\text { coordinators, managers and } \\
\text { workers, as well as among all } \\
\text { collaborators. }\end{array}$ \\
\hline & & $\begin{array}{l}\text { Establish and disseminate clear } \\
\text { instructions to employees for } \\
\text { dealing with problems that prevent } \\
\text { or limit the development of their } \\
\text { work when they arise. }\end{array}$ \\
\hline & & $\begin{array}{l}\text { Training and sensitization of } \\
\text { directors, managers, chiefs and } \\
\text { coordinators for the prevention of } \\
\text { psychosocial risk factors and the } \\
\text { promotion of favorable } \\
\text { organizational environments. }\end{array}$ \\
\hline & \multirow[t]{3}{*}{ Violence } & $\begin{array}{lrr}\text { Guidelines to } & & \text { prohibit } \\
\text { discrimination and } & \text { to } \\
\text { equity and respect } & & \\
\end{array}$ \\
\hline & & $\begin{array}{l}\text { Disseminate information to raise } \\
\text { awareness about workplace } \\
\text { violence, both to workers and to } \\
\text { directors, managers, supervisors } \\
\text { and coordinators. }\end{array}$ \\
\hline & & $\begin{array}{l}\text { Establish follow-up plans to } \\
\text { address issues related to workplace } \\
\text { violence, and train the person } \\
\text { responsible for their } \\
\text { implementation and inform on how } \\
\text { to report acts of workplace } \\
\text { violence. }\end{array}$ \\
\hline
\end{tabular}

Table 3 Specific strategies by risk factor. Source: Self Made

\section{Conclusions}

The data produced by the applied instruments show the psychosocial risk factors (Table 3 ) and the implications that they bring with them, allowing the human resources area of the company under study to develop a series of recommendations to minimize their impact on it.

From the perspective of LA it can be reflected at first instance that these factors can cause deviant behaviors affecting organizational performance, Powerlessness (Impotence), Meaninglessness (lack of meaning), Normlessnes (absence of norms), Isolation (isolation) and Self-strangement. It should be noted that these are first approximations to LA results in the company, since as such it would be necessary to develop a specific instrument to determine the degree of alienation and to be able to correlate this with psychosocial factors.

Without attempting to resolve the debate on the way in which these can coexist and considering the data with which we have available, the appearance of psychosocial risks is presented, negatively affecting the quality of life of the collaborator, thus evidencing the relationship between psychosocial factors and stress labor and above all that the employee can point to the organization as responsible for his state developing in the feeling of helplessness or deviant behaviors.

The causes depend on the existence of socio-emotional, organizational and psychological aspects, which influence the employees; therefore, knowledge and understanding of job alignment and psychosocial risk factors can help select better tools and actions in the organization.

\section{Future recommendations.}

Work circumstances are activities that have been evolving (which presents a new line of research, due to the scarcity of these, or the perspective of analyzing them) for which Human Resources management professionals must reduce work methods little effective. The results of this study will allow to guide the development of strategies aimed at reducing $\mathrm{AL}$ and psychosocial risk factors, thus favoring the subject's alignment with their needs, desires, abilities, feelings, interpersonal relationships and activities themselves. organization with satisfaction. 


\section{References}

Acevedo, G., Sánchez, J., Farías, M. and Fernández A. (2013). Psychosocial risks in the health team of public hospitals in the province of Córdoba, Argentina. Cienc Trab, 15, 140- 147.

Alonso Olea, Manuel (1973), Alienation. One word story. Polytechnic Study Institute, Madrid, 1974.

Benavides, F., Gimeno, D., Benach. J., Martinez, J. M., Jarque, S., \& Berra, A. Description of psychosocial risk factors in four companies. Gac Sanit, 2002, 16.3, 222-229.

Buitrago Mejia, L. D. P., Lopez Lopez, M. P., Cervántez Ordóñez, D. M., \& Lloreda Gómez, E. (2021). Bienestar laboral general en docentes del sector público de Manizales.

Córdoba Reina, K. S. (2021). Diseño de un programa de intervención para el incremento del Bienestar Laboral en un grupo de colaboradores de sector transporte.

Duro, A. (2005a). Quality of Work Life and Social Psychology of Work Health: towards a model of common components to explain psychological work well-being and work mental health of psychosocial origin. Theoretical fundament. Magazine of the Ministry of Labor and Social Affairs. Series Econom-ía y Sociología, 56, 15-56.

García Inga, F. M., \& Cuba Matos, R. M. (2021). Rotación de personal y el estrés laboral en una empresa retail de San Juan de Miraflores 2021.

Granda, S., \& Jadeline, J. (2021). Síndrome de desgaste profesional burnout en médicos posgradistas de la especialidad de terapia intensiva en la ciudad de Quito en el año 2020.

Gurmendez, Carlos (1989). The secret of human alienation and de-alienation. Editorial Anthropos, Barcelona.

Hospital Bertha Calderón Roque. Managua II semestre 2020 (Doctoral dissertation, Universidad Nacional Autónoma de Nicaragua, Managua).

ILO Psychosocial factors at work: recognition and control. Geneva: ILO; 1986.
Jara Diaz, Sergio (1999). Alienation and value of time. Universidad de Chile, sixth series no.9 August 1999.

Jiménez, B. M., \& León, C. B. (2010). Psychosocial factors and risks, forms, consequences, measures and good practices. Autonomous University of Madrid.

Juárez, A., and Camacho, A. (2011a). Theoretical, conceptual reviews of the psychosocial at work. Editorial Juan Pablos / UAEM. First edition. Mexico

Laudon, K. C., and Laudon, J. P. (2000). Management information systems: Organization and technology in the networked enterprise (6th ed.). New York: Prentice-Hall Inc.

Noriega M., Laurell C., Martínez, S. Méndez I., Villegas J (2000). Interaction of work demands in the generation of mental suffering. Cad. Public Health 2000; 16 (4).

Official Mexican Standard NOM-035-STPS2018, Psychosocial risk factors at workIdentification, analysis and prevention, DOF: 10/23/2018.

Pando M; Roman J; Acosta M (2008). Psychosocial risk factors at work in the company. Mexico: CyTED RIPSOL.

Rodríguez Chavarría, K. L., \& Sánchez Rugama, B. L. (2021). Factores relacionados al estrés laboral del personal de enfermería que se desempeña en la sala de alto riesgo obstétrico. 